\title{
Visualization of the morphology and mode of occurrence of Cenomanian rudists within a drillcore by X-ray CT scanning and 3D modeling
}

\author{
Motoyoshi Yamanaka ${ }^{1 *}$, Shin-ichi Sano ${ }^{2}$, Hamad Bu Alrougha Al Zaabi ${ }^{3}$, Hiroshi Fujioka ${ }^{4}$ and Yasufumi Iryu ${ }^{4}$
}

\begin{abstract}
Rudists are a group of bizarrely shaped marine bivalves that lived in the Tethys Ocean from the Late Jurassic to the latest Cretaceous. They are morphologically variable, including snail-like, cup-like, and horn-like shapes. In the Middle East, Cretaceous carbonates with rudists and rudist fragments are well exposed in many outcrops as well as oil and gas fields. For rudist-bearing carbonates in the subsurface, knowledge of rudist morphology and mode of occurrence must be derived from observation of drillcores; however, understanding the three-dimensional (3D) geometry of rudists from observation of core surfaces is difficult. In paleontological studies of rudists, X-ray computerized tomography $(C T)$ scans have been carried out to reconstruct the inside texture of rudist shells for the purpose of taxonomic research. In contrast, in the oil and gas industry, application of X-ray CT scanning technology is generally focused on direct measurement of reservoir properties. Studies of rudist fossils within drillcores by means of X-ray CT have not yet been conducted. We have developed a new protocol to observe core interiors using X-ray CT. We obtained high-resolution 3D images of rudists in a drillcore by means of surface rendering, volume rendering, and $3 \mathrm{D}$ printing. $X$-ray $\mathrm{CT}$ and $3 \mathrm{D}$ modeling is a novel method for non-destructive analyses of the morphology and mode of occurrence of fossils within drillcores.
\end{abstract}

Keywords: X-ray CT scan imaging, Surface rendering, Volume rendering, 3D modeling, Drillcore, Rudist, Abu Dhabi, Cretaceous

\section{Introduction}

The Late Cretaceous was the only time interval in Earth history when bivalves were one of the major components of carbonate platforms. The bivalves were rudists, a group of bizarrely shaped marine bivalves living in the Tethys Ocean from the Late Jurassic to the latest Cretaceous. They are morphologically variable, including snail-like, cup-like, and horn-like shapes. Cretaceous rudist-bearing carbonates are proven exploration targets for hydrocarbons and form the reservoirs of a number of

\footnotetext{
* Correspondence: motoyoshi.yamanaka@inpex.co.jp

1JODCO Exploration Limited, 10th Floor, Tower 3, Etihad Towers, P.O. Box 2659, Abu Dhabi, UAE

Full list of author information is available at the end of the article
}

giant fields, including the Bu Hasa, Fateh, Fahud, Idd El Shargi, Rumaila, Shaybah, Shah, and Umm Al-Dalkh fields (Neo 1987, 1996; Scott 1990; Alsharhan and Nairn 1993; Alsharhan 1995; Al-Zaabi et al. 2010; van Buchem et al. 2011; Yamamoto et al. 2016; Kojima et al. 2017; Yamanaka et al. 2018, 2019a). In the case of the Cenomanian-lower Turonian Mishrif Formation, which is an important reservoir rock throughout the Middle East, high porosity and permeability are restricted to the rudist-bearing facies, which therefore constitute the main oil-producing reservoir zones in this formation. (Alsharhan 1995). The mode of occurrence (presence/absence, distribution, whether autochthonous or allochthonous, and sedimentological roles) of rudists in carbonate platforms is of scientific 
importance. The depositional environment of rudistbearing carbonates and their porosity and permeability are closely related and, thus, important for oil/gas exploration (e.g., Yamanaka et al. 2019b). This is the case for Upper Cretaceous platform carbonates in the southern Arabian Peninsula including at Abu Dhabi (Burchette and Britton 1985; Burchette 1993; Skelton et al. 1995; Cestari and Sartorio 1995; Özer et al. 2009).

Cretaceous rudist-bearing carbonates are widespread in the Arabian Peninsula in outcrop and in the subsurface. Observations regarding rudist morphology and taxonomy have been mainly derived from outcrop studies (Skelton and Masse 2000; Schumann 2000), and this knowledge is the starting point for use of rudists for sedimentological and paleontological analyses of drillcores. However, in drillcore analyses, observations are limited to the two-dimensional (2D) core surface and it is therefore very difficult to obtain three-dimensional (3D) information on the sedimentary structure and morphology of macrofossils, including rudists.

To increase the amount of information that can be obtained from core observation, a 3D imaging technique using X-ray computerized tomography (CT) has been introduced to the fields of sedimentology (Seard et al. 2010) and paleontology (e.g., Sutton et al. 2014; Racicot 2016), and successful outcomes have already been achieved.

Hughes et al. (2004) attempted to analyze the outer and inner morphology of rudists within drillcores using $\mathrm{X}$-ray CT images. However, it was very difficult to delineate the morphology of carbonate shells embedded in a carbonate matrix with $\mathrm{CT}$ values achievable at that time, and only a dim outline of the outer morphology was distinguished. Subsequent studies (Molineux et al. 2007; Molineux et al. 2010) of rudist morphology using X-ray CT images dealt with silicified material isolated from a carbonate matrix. Recently, the spatial resolution of Xray $\mathrm{CT}$ images has been greatly increased and new image-processing techniques such as surface rendering and volume rendering have been invented and markedly improved. In addition, 3D printers can create precise plastic figures of objects at low cost. In this article, these advanced techniques are applied to rudist-bearing core samples, yielding clearly delineated 3D images. Here, we demonstrate the first use of 3D images of rudists for identification of rudisit taxa and characterization of fossil occurrences. These advanced techniques will be applicable to many types of fossil and, thus, are expected to significantly facilitate progress in paleontology.

\section{Methods/experimental}

\subsection{Material}

In this study, one core was collected from Cenomanian carbonates in the "A field" located offshore of the United
Arab Emirates (UAE) and $20 \mathrm{~km}$ northeast of Abu Dhabi City (Fig. 1). A reservoir horizon in the A field consists of Cenomanian shallow water, rudist-bearing carbonates (Neo 1987; Al-Zaabi et al. 2010; Yamamoto et al. 2016). Five radiolitid genera (Sphaerulites, Praeradiolites, Eoradiolites, Sauvagesia, and Durania) and one ichthyosarcolitid genus (Ichthyosarcolites) comprise most of the rudist occurrences in the Cenomanian carbonate platform outcrops of northern Oman (Philip et al. 1995). Similar rudist assemblages are known from Cenomanian strata in Sinai, Egypt (Saber et al. 2009; Zakhera 2011). Broken and intact rudist shells belonging to these taxa are common to abundant and are locally associated with autochthonous specimens in the high-energy platform margin/barrier facies of the Cenomanian-lower Turonian sequences on the eastern Arabian Plate (e.g., Alsharhan and Nairn 1993; van Buchem et al. 2011). Therefore, radiolitid and ichthyosarcolitid rudists were expected to occur in the studied cores.

A core drilled and recovered from shoal facies in this field comprised grainstone-packstone-wackestone containing common gravel-sized rudists and fragments of those rudists. The studied material was a one-third split of a seven-inch-diameter core (hereafter termed "the core"; $8 \mathrm{~cm}$ long, $7 \mathrm{~cm}$ wide) of the packstone (Fig. 2ae). Rudist fragments were randomly scattered on the core surface.

The studied material is stored in the Technical Research Center of INPEX Corporation at Tokyo, Japan.

\subsection{Work flow}

The work flow followed in the present study is summarized in Fig. 3. X-ray CT scanning of the core was undertaken after initial visual observation of the core surface, followed by detailed visual study of fossil rudists on the core surface taking into account the Xray $\mathrm{CT}$ scan results. We used a third-generation dualsource medical X-ray CT scanner (SIEMENS, SOMATOM Definition Flash, Munich, Germany) at the Technological Research Center of the Japan Oil, Gas and Metals National Corporation, Chiba, Japan. A single-source X-ray was utilized with tube voltage optimized to $140 \mathrm{kV}$ and a scanning interval of $0.5 \mathrm{~mm}$. Approximately 160 slice images were obtained from the studied core. A "CT value" represents the relative density of an object relative to water (zero) and air (-1000) and is expressed in Hounsfield units. For example, CT values of hard tissues such as bones and teeth range from 300 to $>1000$. In typical X-ray CT images calculated from CT values, darker colors represent soft tissues or porous areas such as pores, whereas lighter colors indicate hard tissues or dense (non-porous) areas such as rock. As a result, gray-scale slice images can be obtained at a resolution of $0.2 \mathrm{~mm}$ pixel $^{-1}$. 


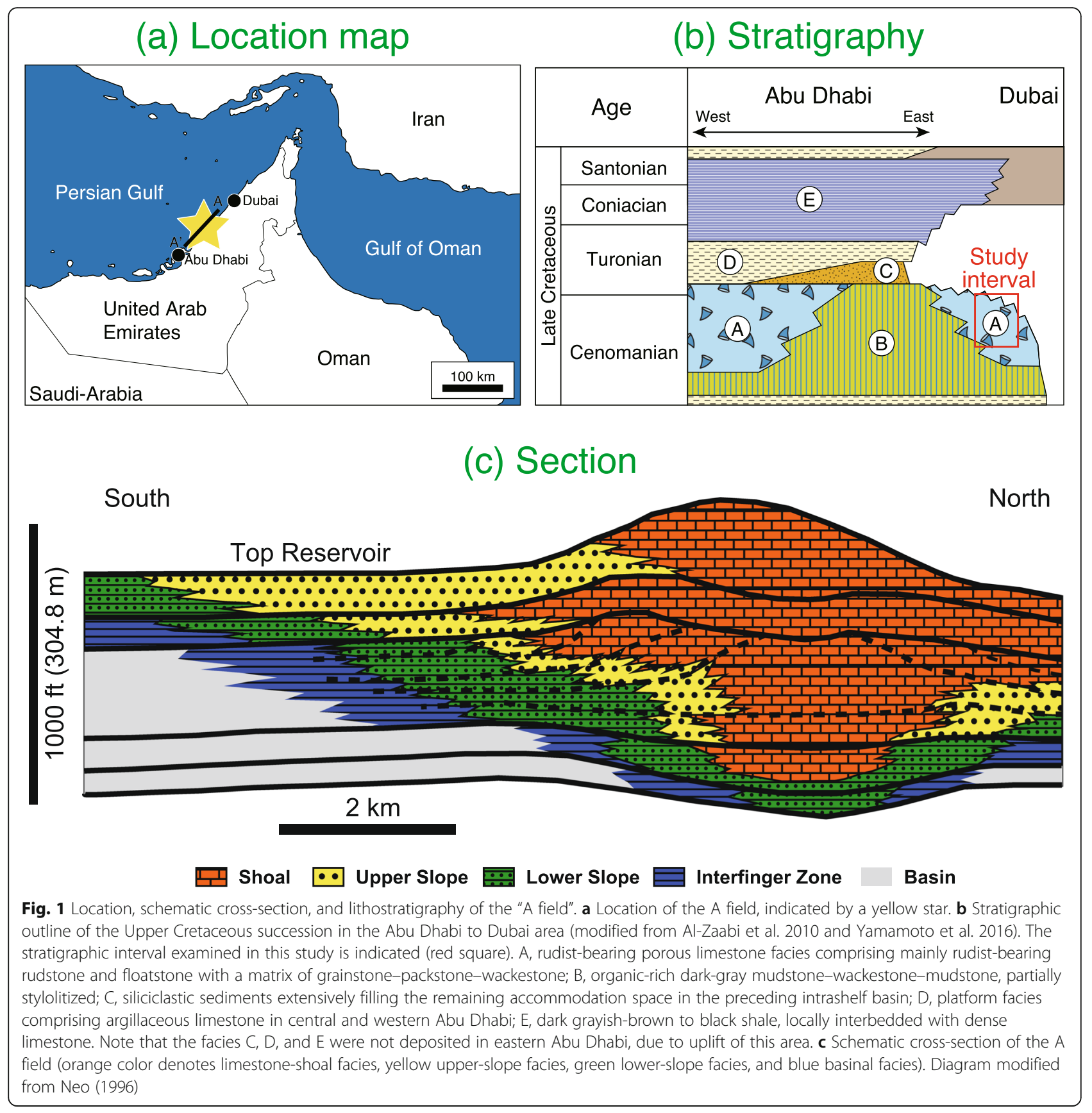

We applied "surface rendering" and "volume rendering" to X-ray CT scan data to visualize 3D structures using Molcer Plus software (White Rabbit Ltd., Tokyo, Japan). Surface rendering is a method for viewing the surfaces of masses above a certain threshold of CT value. Volume rendering is a method for changing opacity to make the interior contents visible. Surface rendering is a drawing of the "equality surface," which is a closed surface that allows voxel data to be double-valued at a certain threshold and corresponds to the topographic contours of the material. Surface rendering is usually composed of a collection of triangular polygons, while volume rendering displays all voxel values. We created volume-rendering images following three steps: at first time, determine any one direction, from this voxel column, (1) display the highest value; (2) add a back-side voxel value to a front-side voxel value continuously in a line voxel and change the color (pseudo-color) and transparency on the basis of the voxel values; and (3) prioritize where the voxel values change abruptly. One 


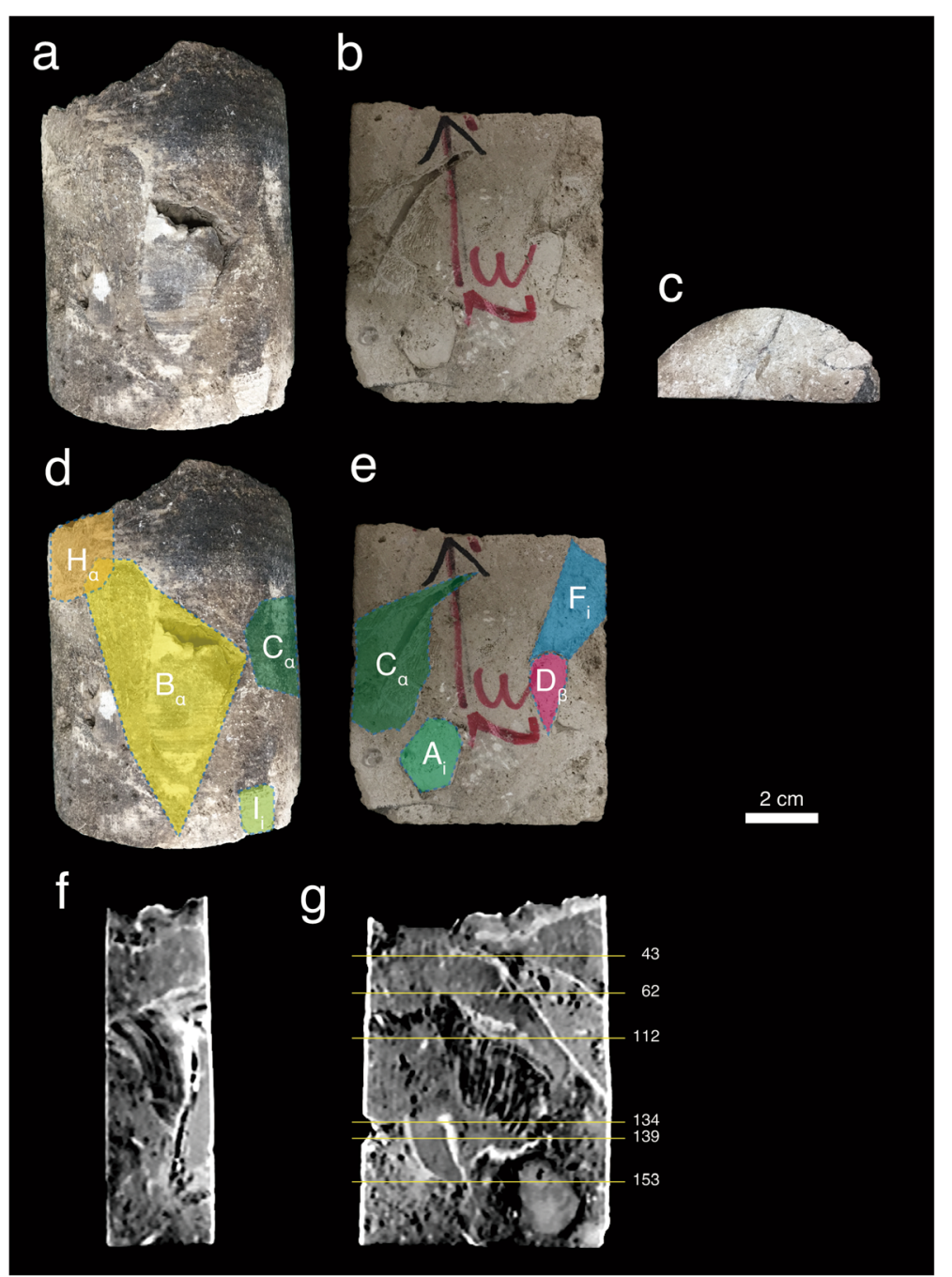

Fig. 2 Core photographs and X-ray CT images. a-e External appearance of the core. Note that rudists A-D, F, H. and I are indicated. a, d Side view of the external core surface. $\mathbf{b}$, e Side view of the split core surface. c Top view. $\mathbf{f}, \mathbf{g}$ Vertical slice images of the core obtained by X-ray CT. $\mathbf{f}$ Side view. $\mathbf{g}$ Side view of the core at $\sim 0.5 \mathrm{~cm}$ from the external surface. Horizontal slice images of the numbered horizons $(43,62,112,134,139$, and 153) are shown in Fig. 4. a, Radiolitidae a with a thick outer layer; $\beta$, Radiolitidae $\beta$ with a thin outer shell layer; i, Ichthyosarcolites

3D-printed model was made to identify the growth history of a rudist based on the results of the surface rendering (for more details regarding the surface and volume rendering, see Additional file 1: Document S1). The rudist (rudist B; see below) had a thick outer shell layer and was preserved in growth position near the center of the core sample. We created a transparent resin model with a 3D printer (Objet500 Connex3, Stratasys 3D printer, Tokyo, Japan) at the Tokyo Metropolitan Industrial Technology Research Institute, Tokyo, to visualize the internal structure of the core. We used a transparent resin, Veroclear (Stratasys Ltd., Eden Prairie, MN, USA). The outer and the inner shell layers were produced in different colors; magenta for the inner and cyan for the outer. The mold was polished using a compound to remove the modeling marks. The resin model is stored in INPEX Corporation at Tokyo, Japan.

\section{Results and discussion}

By comparing the visual core surface observation, surface rendering, volume rendering, and 3D modeling, we discriminated four types of rudists: (1) Radiolitidae $\alpha$ with a thick outer layer; (2) Radiolitidae $\beta$ with a thin outer shell layer; (3) Radiolitidae $\gamma$, characterized by its large size; and (4) Ichthyosarcolites (Figs. 2, 4, and 5).

Ten individual rudists assigned to the four types were identified in the core, with the following succession from the bottom to the top: I, Ichthyosarcolites; A, Ichthyosarcolites; $\mathrm{B}$, Radiolitidae $\alpha$, showing its early growth stage; D, Radiolitidae $\beta$; E, Radiolitidae $\beta$; G, Radiolitidae $\beta$; F, 


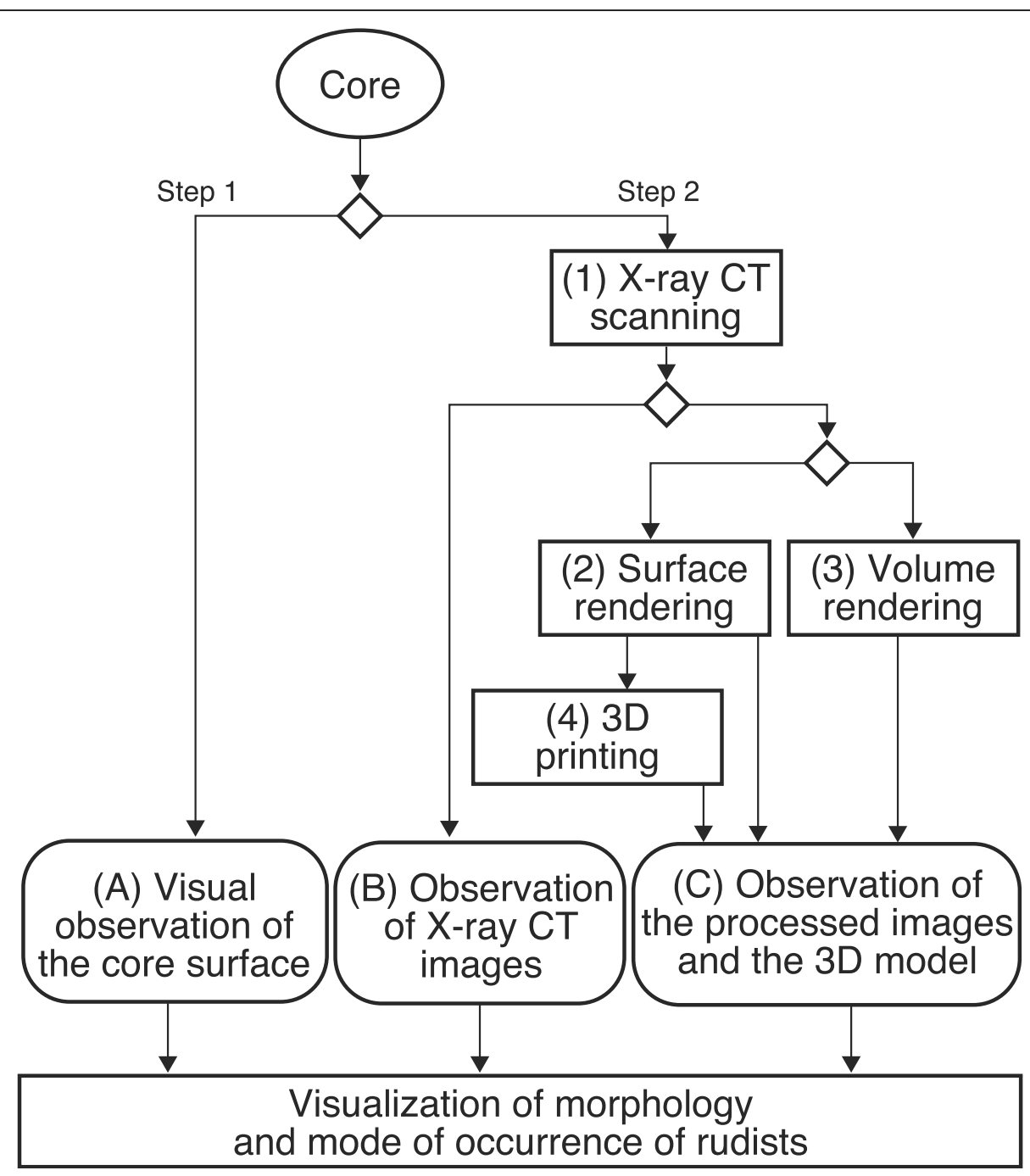

Fig. 3 Flow chart of the $X$-ray $C T$ image analysis conducted in the present study.Two steps of image analysis were conducted for rudists in the studied core. Step 1 was visual observation of rudists at the core surface (A). Step 2 included direct observation (1, B) and processing of X-ray CT images of rudists in the core interior. To understand rudist morphology and spatial configuration, two techniques were adopted for X-ray $C T$ image processing: surface rendering (2) and volume rendering (3) (further details of the surface rendering and volume rendering are provided in Additional file 1: Document S1). From the results of the surface rendering, one 3D-printed model was made (4). By integrating all results, we visualized the morphology and mode of occurrence of the rudists

Ichthyosarcolites; C, Radiolitidae $\alpha ; \mathrm{H}$, Radiolitidae $\alpha$; and J, Radiolitidae $\gamma$.

\subsection{Visual observation of the core surface and X-ray CT scan imaging}

Seven rudists were identified during initial visual observation of the core surface: four on the external core surface (rudists B, C, H, and I; Fig. 2d) and four on the split core surface (rudists A, C, D, and F; Fig. 2e). Of these, two rudists ( $B$ and $C$ ) were relatively more noticeable. Rudist B lay in the center part of the external core surface (Fig. 2d, e). This rudist had a conical external shape, grew upward, and exhibited visible celluloprismatic structure in its outer shell layer. The growth of rudist $\mathrm{C}$ was directed downward, suggesting an allochthonous mode of occurrence (Fig. 2e).

$\mathrm{X}$-ray CT scan images enabled us to clearly differentiate rudists, matrix, and dissolution cavities even if the rudists were somewhat broken and fragmented (Fig. 2f, g). A series of slice images obtained from the X-ray CT scan was useful in revealing outer shapes, internal structures, and configurations of rudists in the core. We describe the rudists in detail below (Additional file 2: Figure S1).

Three slice images were obtained from the upper (slice numbers 43, 62, and 112; Fig. 4a-c) and lower 


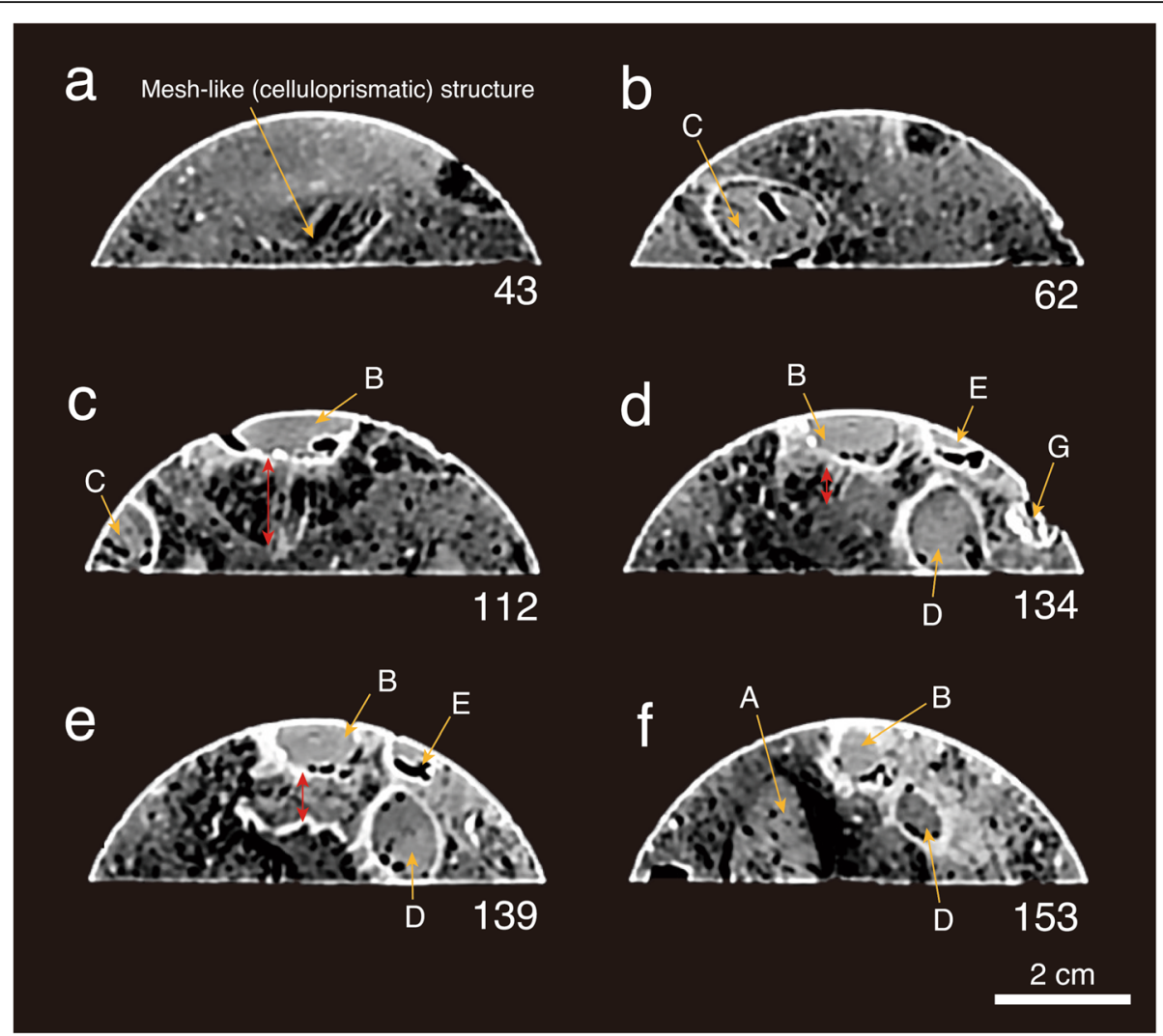

Fig. 4 Horizontal slice images obtained by X-ray CT. a Upper-upper slice (slice number 43 in Fig. 2). Note mesh-like (celluloprismatic) structure in the center. b Upper-middle slice (slice number 62 in Fig. 2). Note rudist C on the left-hand side. c Upper-lower slice (slice number 112 in Fig. 2). Note rudists B and C. d Lower-upper slice (slice number 134 in Fig. 2). Four rudists (rudists B, D, E, and G) are present. e Lower-middle slice (slice number 139 in Fig. 2). Three rudists (rudists B, D, and E) are present. f Lower-lower slice (slice number 153 in Fig. 2). Three rudists (rudists A, D, and B) are discernible. Rudist B possesses the thick outer shell layer (red arrows in $\mathbf{c}, \mathbf{d}$, and $\mathbf{e}$ ). Yellow arrows in $\mathbf{b}$-f $\mathbf{f}$ indicate individual rudists

(slice numbers 134, 139, and 153; Fig. 4d-f) parts of the core. Mesh-like (celluloprismatic) shell structure (rudist C) was recognized in the central part of the uppermost slice (slice number 43; Fig. 4a). Rudist C occurred also in the left-hand side of the uppermiddle slice (slice number 62; Fig. 4b), which was 9.5 $\mathrm{mm}$ below slice number 43. In the upper-lower slice (slice number 112; Fig. 4c), two rudist shells (rudists B and C) were recognized. Rudist B had a thick outer shell layer (red arrows in Fig. 4). Four rudist shells (rudists B, D, E, and G) occurred in the lower-upper slice (slice number 134; Fig. 4d); of these, rudist B preserved a thick outer shell layer. In the lowermiddle slice (number 139; Fig. 4e), which was $2 \mathrm{~mm}$ below the lower-upper slice, three rudist shells (rudists B, D, and E) were discernible. Rudist B still possessed a thick outer shell layer. Three rudist shells (rudists A, D, and B) were present in the lowermost slice (number 153; Fig. 4f).
An outer shell layer was not recognized in rudist A. The slice images indicated that rudist $\mathrm{B}$ was preserved in an upright position and had a thick outer shell layer. The boundary between the inner and outer shell layers could be easily recognized, although the inner shell layer was mostly dissolved. The lattice-like (celluloprismatic) outer shell layer of rudist $\mathrm{C}$ was not apparent in the X-ray CT scan images, although it could be detected by visual core surface observation. This difference in the visibility of the structure is related to X-ray $\mathrm{CT}$ resolution. Because the scanning interval of the X-ray CT image was 0.5 $\mathrm{mm}$ per slice, detail that is less than this size, such as the celluloprismatic structure of the outer shell layer, cannot be detected.

From visual observation of the core surface and X-ray CT scan imaging, nine rudists (rudists A-I) were identified. These rudists were grouped into two types on the slice images: rudists possessing a thick outer shell layer (rudists $\mathrm{B}, \mathrm{C}$, and $\mathrm{H}$ ) and rudists lacking a thick shell 


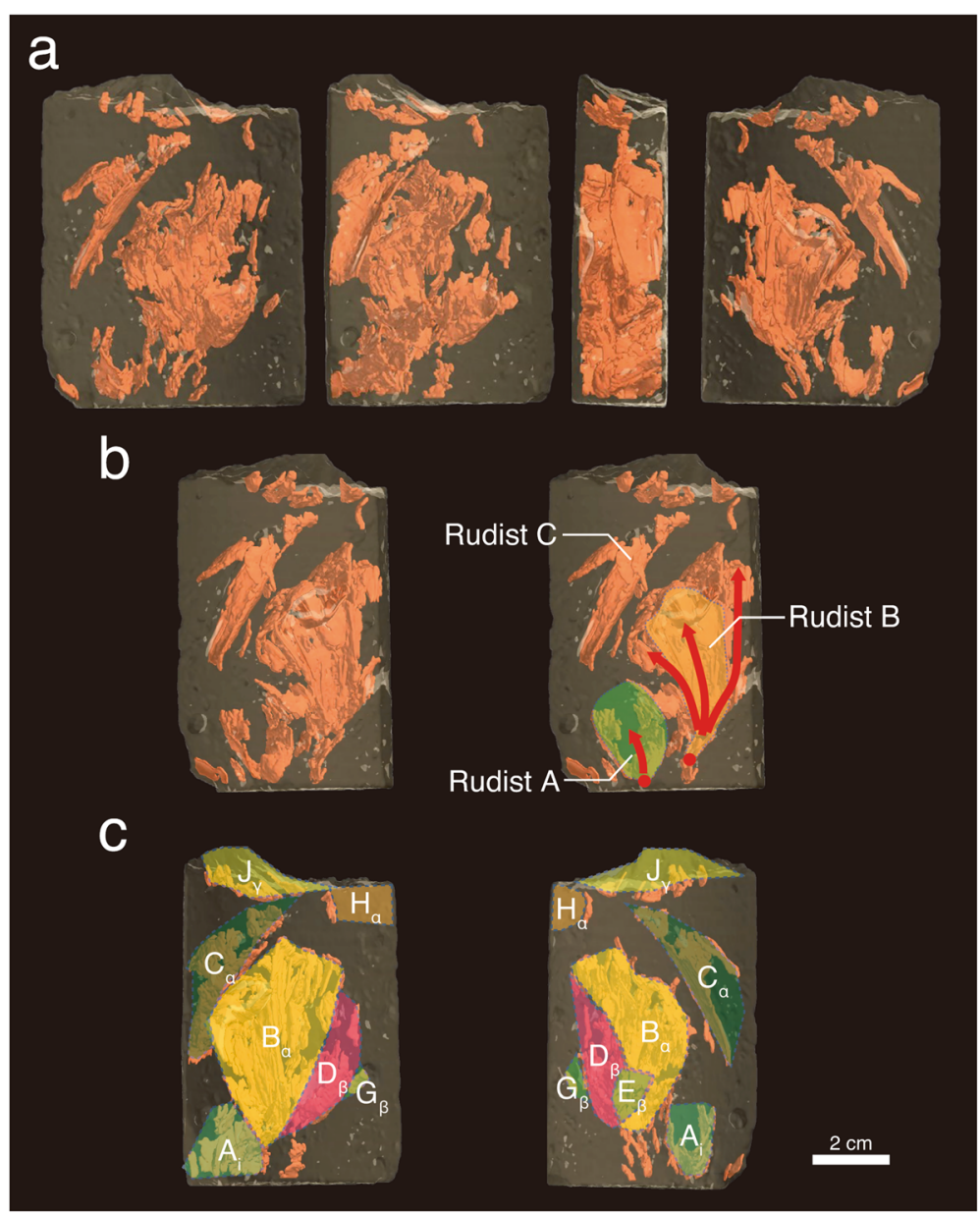

Fig. 5 X-ray CT images processed with a surface-rendering technique. a Surface-rendering-processed images of the studied core. The images are shown in clockwise rotation from the external core surface (left) to the split core surface (right). Orange color indicates rudists inside the core. $\mathbf{b}$ Surface-rendering-processed image (left) and its interpretation (right). Red lines and dots indicate the growth directions and spats from which the shell growth started, respectively. c Occurrences of rudists detected by the surface-rendering technique (left: external core surface, right: split core surface)

layer (rudists A, D-G, and I). Rudist C had a thick outer shell layer, which was confirmed to be present by visual observation of the core but not by X-ray CT imaging.

\subsection{Surface rendering}

Evaluation of the whole morphology of rudists in drillcores based on the limited and fragmentary information obtained by visual core surface observation is difficult. It is possible, by applying a surface-rendering technique to $\mathrm{X}$-ray CT images of drillcores, to connect such limited and fragmentary information together to yield a single image and to understand how the shells of individual rudists developed (Fig. 5; Additional file 3, Figure S2). This new information will facilitate taxonomic and paleoecological studies of rudists.

The images produced by applying the surfacerendering technique show that rudist $\mathrm{B}$, which is cone- shaped, was located in the central part of the studied core (Fig. 5), in close proximity to rudist A below and rudist $\mathrm{C}$ above. The images also indicate that rudist $\mathrm{A}$ grew obliquely to the sea bottom and may have retained its growth position in bioclastic sediments during burial. Rudist B settled on a hard substrate (see "volume rendering") immediately adjacent to rudist A shortly after settlement of the latter judging from the short distance between the base of the two rudists. Rudist B grew in a conical shape while developing the thick outer shell layer. It is noteworthy that the surface-rendering technique made apparent the isolation of rudist $\mathrm{B}$ from rudists $A$ and $C$; in other words, the outer layer of rudist $B$ was not connected with those of rudists A and C. Rudist $C$ was an allochthonous, fragmented shell in an inverted position overlying rudist $B$, suggesting postmortem transportation of the former. The reconstructed 


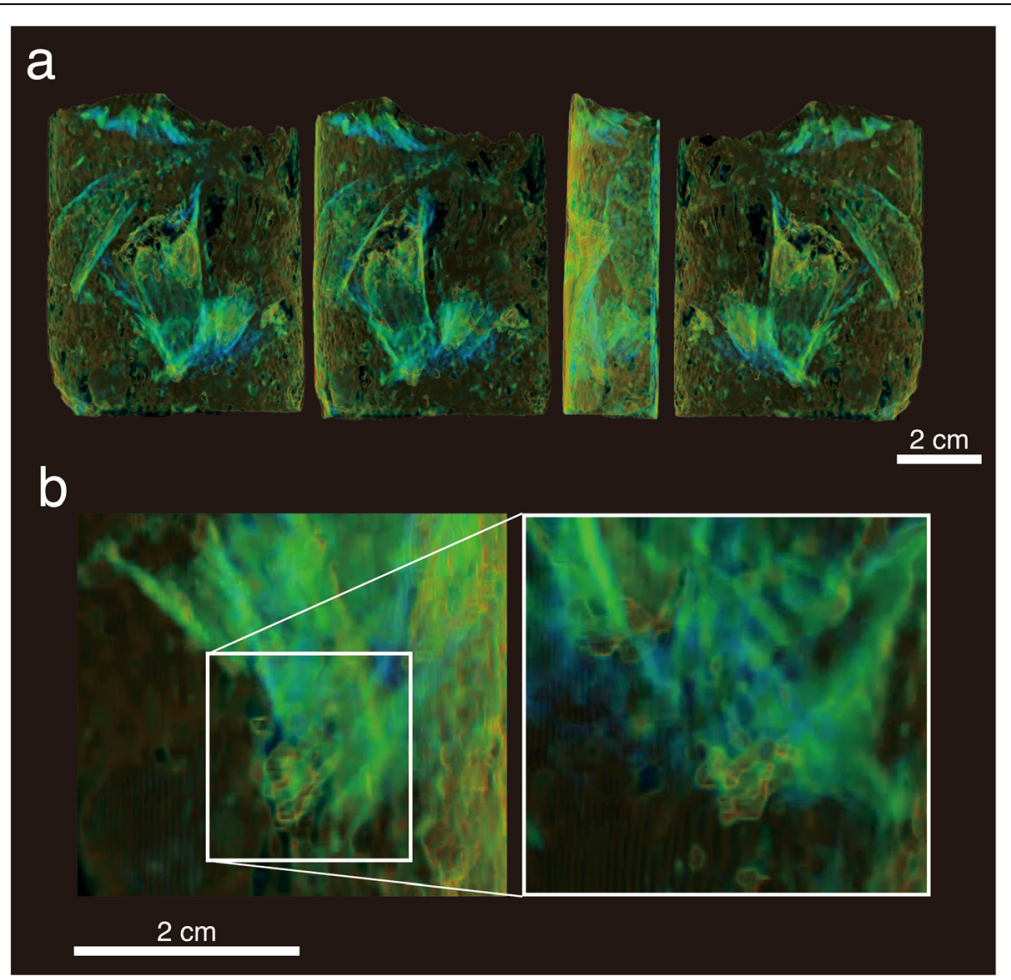

Fig. 6 X-ray CT images processed with a volume-rendering technique. a Volume-rendering-processed images of rudist B in the studied core. The images are shown in clockwise rotation from the external core surface (left) to the split core surface (right). $\mathbf{b}$ Enlarged images of the spat of rudist $B$

succession indicates that three rudists did not bud from individuals located below (in other words, did not settle on individuals located below) but grew independently. The images produced with the surface-rendering technique also demonstrate that rudists $\mathrm{D}$ and $\mathrm{E}$ started to grow on the flank of rudist B near its base (Fig. 5c).

\subsection{Volume rendering}

Volume rendering, unlike surface rendering, makes it easier to recognize objectives as hologram images (Fig. 6a; Additional file 4: Figure S3). Volume rendering revealed two modes of rudist occurrence in the core: in the original growth position (four rudists: rudist A and

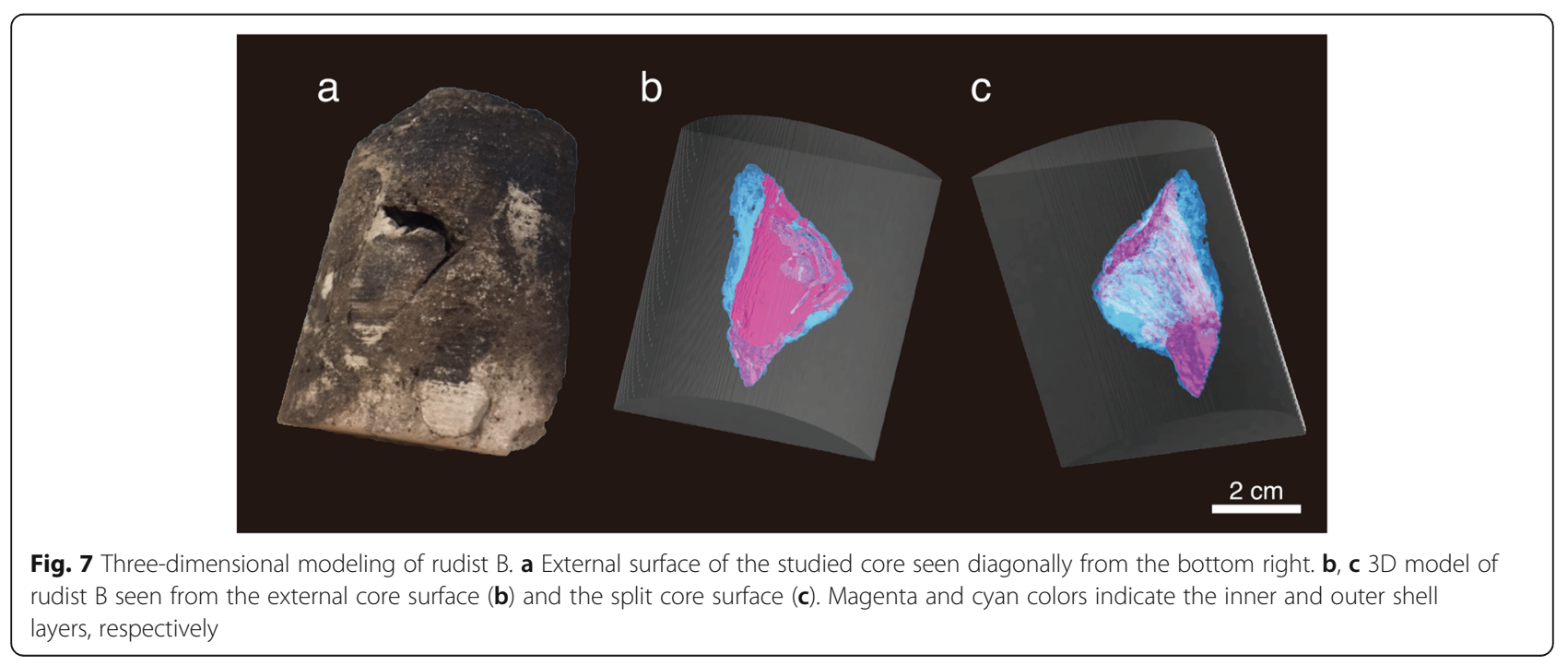


possibly rudists $\mathrm{B}, \mathrm{D}$, and $\mathrm{G}$ ); and fragmented and in a standing or inverted position (e.g., rudist C; Fig. 5).

The detailed images (Fig. $6 \mathrm{~b}$ ) of the basal part of rudist $B$ clearly indicate that its growth began from the settlement of a juvenile (spat in Figs. 5 and 6) on a hard substrate such as a rock or a shell fragment. This finding is consistent with the direct observation of settling of juvenile specimens onto gravel or the shells of adult rudists (Gili and Götz 2018).

This type of growth process is generally difficult to infer from visual observation of core surfaces because the observable area is very limited $(8 \mathrm{~cm}$ long and $7 \mathrm{~cm}$ wide), and the interior of the core is not visible. Volume rendering enables rotation of 3D images, which is useful in taxonomic identification and analysis of the mode of occurrence of rudists. However, experience of the technique is required to determine the threshold at which CT values should be rejected as noise on the image of the rudist surface during 3D modeling.

\subsection{D printer modeling}

To visually understand the relationship between the inner shell layer and the outer shell layer (Fig. 7; Additional file 5: Figure S4), we made a 3D-printed model using the surface-rendering technique for rudist $\mathrm{B}$, which is preserved in an upright position and has a relatively thick outer shell layer (Fig. 8). The created 3Dprinted model yielded information on the growth history of rudist B. Figures 7 and 8 indicate that the outer shell layer started to be developed from $7 \mathrm{~mm}$ above the base of the inner shell layer, and subsequently extended upward to wrap around the inner shell layer. Finally, both inner and outer shell layers grew upward together.

The 3D-printed model also clearly shows the settlement of the juvenile of rudist B. This is the first detection of a rudist spat in the interior of a core.

\subsection{Evaluation of X-ray CT imaging and image processing}

We show, in Fig. 9, a comparison of the occurrence of rudists detected by visual observation of the core (Fig. 9a, b), the surface-rendering technique (Fig. 9c, d), and the 3D-printed model (rudist B, Fig. 9e). We identified seven rudists by means of visual observation of the core surface and extracted limited information on their morphology and mode of occurrence (preservation state, spatial distribution, and growth history). However, the combination of several methods allowed identification of 10 rudists assigned to four types in the studied core. Surface and volume rendering were useful in identifying the initiation (settlement), development, and succession of rudists in the core interior. The volume-rendering technique and the making of a 3D model from a transparent resin allowed observation of the rudists from all directions.

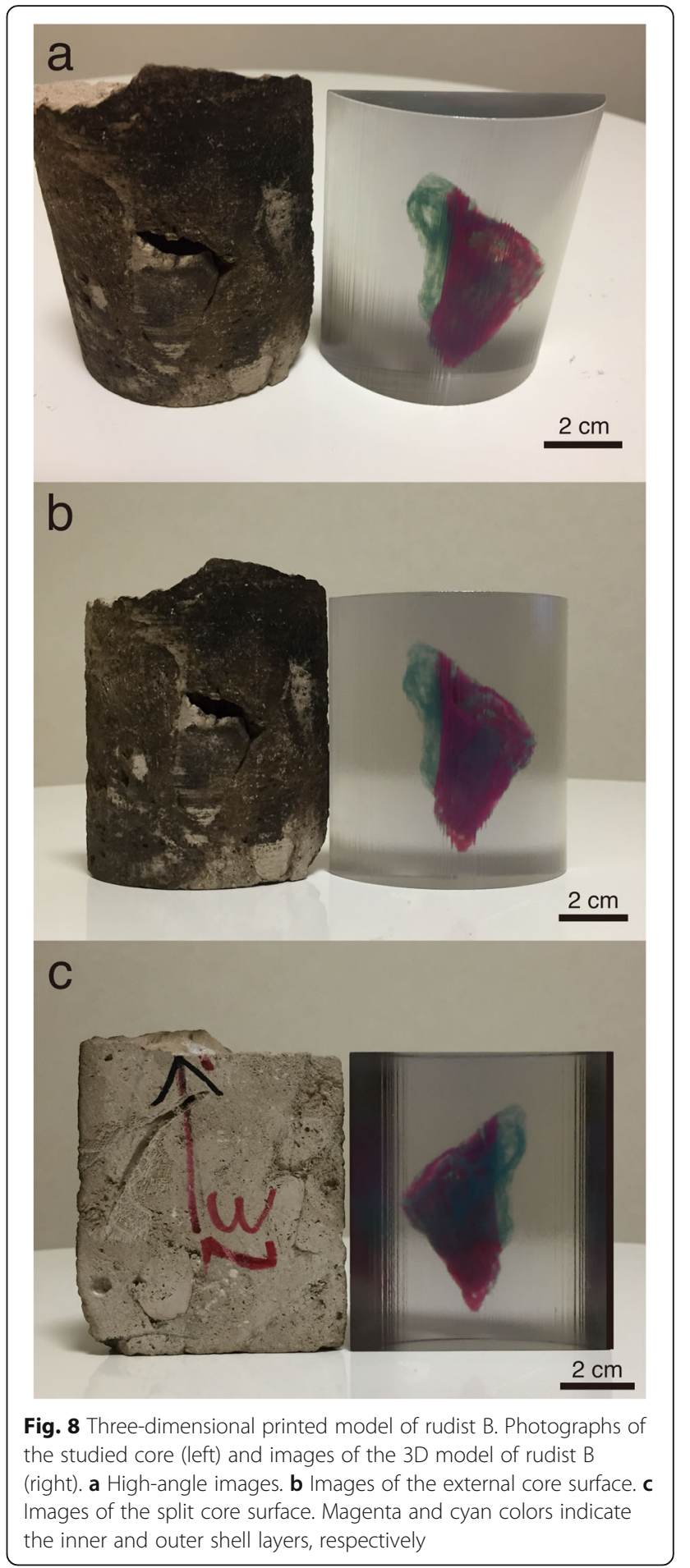

\section{Conclusions}

$\mathrm{X}$-ray CT imaging, combined with surface rendering, volume rendering, and 3D modeling, allows us to obtain various types of information on rudists, such as their morphology (including the presence/absence of pores/ voids within shells), mode of occurrence (including 


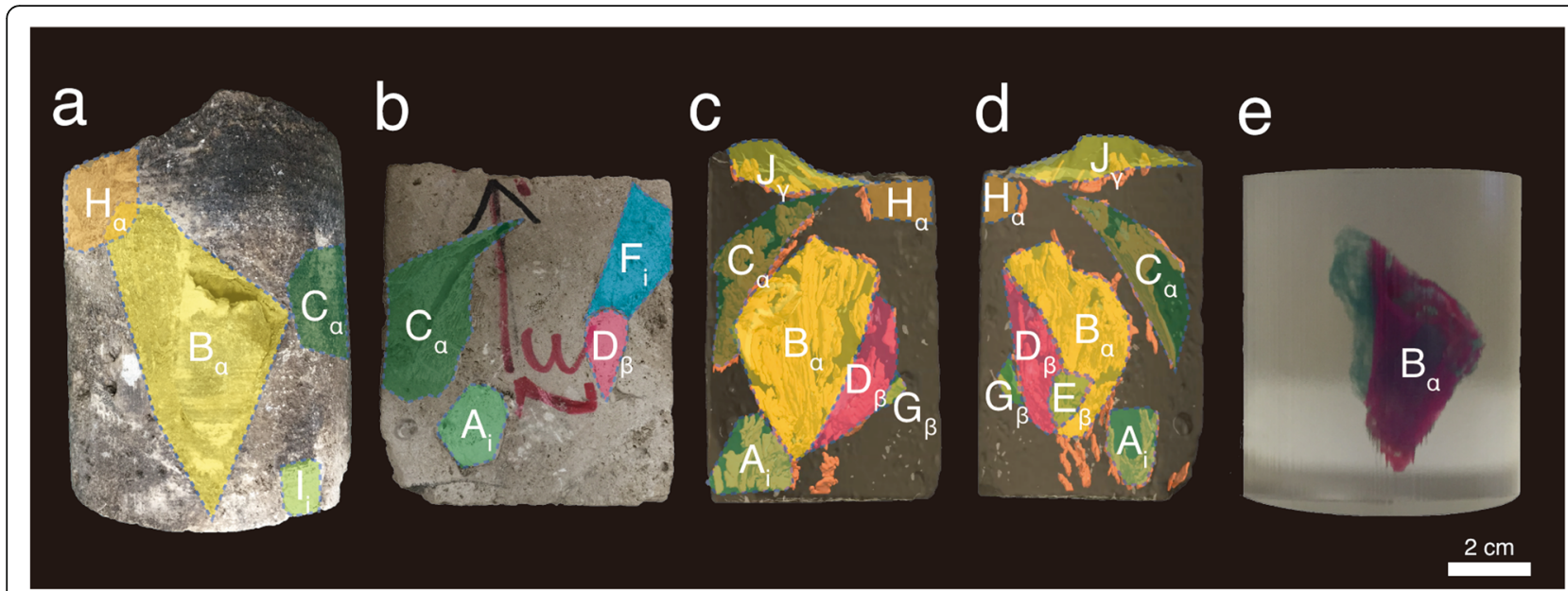

Fig. 9 Visualization of the morphology and mode of occurrence of rudists in the studied core. Comparison of the occurrences of rudists detected by visual observation: a external core surface, $\mathbf{b}$ split core surface; and the surface-rendering technique: c external core surface, $\mathbf{d}$ split core surface. The 3D model of rudist B is also shown (e). Magenta and cyan colors indicate the inner and outer shell layers, respectively

preservation states), and distribution in core samples. This information will be useful in analyzing the sedimentary facies and paleoenvironment of rudist-bearing carbonates and the paleoecology of rudists. We consider that, if X-ray CT images become part of the routine work of core analysis, this process will yield an important database for taxonomic, phylogenetic, and functional morphological research on many fossils as well as sedimentological analysis of various deposits regardless of their geological ages.

Application of X-ray CT imaging to petroleum engineering has already led to advances in our understanding of quantitative representation of the porosity and permeability of oil and gas reservoir rocks. The combination of X-ray CT imaging with the three techniques for visualizing the CT data allows us to clarify the morphology and vertical and spatial development of rudist bioherms/biostromes and delineate their initiation, development, and demise. This information is essential for creating and improving geological models for oil/gas exploration. In addition, our new techniques for studying core samples, in combination with direct visual observation, enable identification of rudists at the species level if they are in a good state of preservation, which will facilitate future studies of rudist biostratigraphy. Furthermore, we can accurately estimate the number of rudists in a sample and delineate their occurrence (e.g., autochthonous or allochthonous), which is essential for reconstructing rudist paleoecology.

Our study clearly indicates that X-ray CT imaging and related techniques can yield new visual data that have not yet been collected. This source of new information will potentially expand our paleontological and paleoecological knowledge as well as assist in development of oil and gas exploration technology. Many drillcores have been obtained for oil and gas exploration in many fields, leaving numerous core samples that have been left uninvestigated after conventional measurements and analysis. Our results highlight the potential of such cores as an important data source for future studies in Earth science.

\section{Supplementary information}

Supplementary information accompanies this paper at https://doi.org/10. 1186/s40645-020-00359-7.

Additional file 1: Document S1 Notes on the surface and volume rendering techniques.

Additional file 2: Figure S1 Movie file of $X$-ray $C T$ imaging.

Additional file 3: Figure S2 Movie file of $X$-ray $C T$ imaging processed with a surface-rendering technique.

Additional file 4: Figure S3 Movie file of X-ray $C T$ imaging processed with a volume-rendering technique.

Additional file 5: Figure S4 Movie file of the $3 D$ model of rudist $B$.

\section{Abbreviations}

3D: Three-dimensional; CT: Computed tomography

\section{Acknowledgements}

The authors thank ADNOC Offshore and INPEX Corporation/Japan Oil Development Company (INPEX/JODCO) for their support and permission to publish this work. The authors also thank the Japan Oil, Gas and Metals National Corporation (JOGMEC) and White Rabbit for their support and assistance with the core observation, sampling, and 3D image modeling. The manuscript was significantly improved by the comments and suggestions of K. Endo (editor) and two anonymous reviewers. 


\section{Authors' contributions}

MY and SS conceptualized and designed this study. MY conducted the X-ray $\mathrm{CT}$ imaging and image processing. SS performed paleontological analysis. SS, $H A Z$, HF, and YI collaborated with the corresponding author in the interpretation of the data and the construction of the manuscript. All authors read and approved the final manuscript.

\section{Funding}

This work was partly supported financially by JODCO Exploration Limited and Grant-in-Aid for Scientific Research from the Japan Society for the Promotion of Science (JSPS KAKENHI) to Y.I. (26302008).

\section{Availability of data and materials}

Please contact the corresponding author regarding data requests.

\section{Competing interests}

The authors declare that they have no competing interests.

\section{Author details}

'JODCO Exploration Limited, 10th Floor, Tower 3, Etihad Towers, P.O. Box 2659, Abu Dhabi, UAE. ${ }^{2}$ Department of Earth System Science, School of Sustainable Design, University of Toyama, Gofuku, Toyama 930-8555, Japan. ${ }^{3}$ Satah \& Umm Al Dalkh Field Development Division, ADNOC Offshore, P.O. Box 303, Abu Dhabi, UAE. ${ }^{4}$ Institute of Geology and Paleontology, Graduate School of Science, Tohoku University, Aobayama, Sendai 980-0856, Japan.

\section{Received: 13 February 2020 Accepted: 6 August 2020}

\section{Published online: 14 September 2020}

\section{References}

Alsharhan AS (1995) Facies variation, diagenesis, and exploration potential of the Cretaceous rudist-bearing carbonates of the Arabian Gulf. AAPG Bulletin 79: 531-550. https://doi.org/10.1306/8D2B1584-171E-11D7-8645000102C1865D

Alsharhan AS, Nairn AEM (1993) Carbonate Platform Models of Arabian Cretaceous Reservoirs. In: Simo JA, Scott RW, Masse JP (eds) Cretaceous Carbonate Platforms. AAPG Memoir, no 56, American Association of Petroleum Geology, Tulsa, Oklahoma, USA, pp 173-184

Al-Zaabi M, Taher A, Azzam I, Witte J (2010) Geological overview of the Middle Cretaceous Mishrif Formation in Abu Dhabi. In: Abu Dhabi International Petroleum Exhibition and Conference, 1-4 November, Abu Dhabi, UAE. Society of Petroleum Engineers, Richardson, Document ID: SPE-137894-MS. https://doi.org/10.2118/137894-MS

Burchette TP (1993) Mishrif Formation (Cenomanian-Turonian), southern Arabian Gulf: carbonate platform growth along a cratonic basin margin. In: Simo JA, Scott RW, Masse J-P (eds) Cretaceous Carbonate Platforms. AAPG Memoir, no 56, AAPG, Tulsa, Oklahoma, USA, pp 185-199

Burchette TP, Britton SR (1985) Carbonate facies analysis in the exploration for hydrocarbons: a case-study from the Cretaceous of the Middle East. In: Benchley PJ, Williams BPJ (eds) Sedimentology: recent developments and applied aspects. Geological Society of London, Special Publications, no 18, pp 311-338

Cestari R, Sartorio D (1995) Rudists and facies of the periadriatic domain. Agip, San Donato Milanese

Gili E, Götz S (2018) Treatise Online no. 103: Part N, Volume 2, Chapter 26B: Paleoecology of rudists. Paleontological Institute, University of Kansas, Lawrence. https://doi.org/10.17161/to.v0i0.7183

Hughes GW, Shameem S, Sadler RK (2004) Computerized tomography reveals Aptian rudist species and taphonomy. Geol Croat 57:67-71

Kojima K, Yamanaka M, Taniwaki T, Amo M, Chiyonobu S (2017) Evaluation of late Cretaceous Cenomanian petroleum system in offshore Abu Dhabi with geochemical analysis. In: Abu Dhabi International Petroleum Exhibition \& Conference, 13-16 November, Abu Dhabi, UAE. Society of Petroleum Engineers, Texas, Document ID: SPE-188389-MS. https://doi.org/10.2118/ 188389-MS

Molineux A, Scott RW, Ketcham RA, Maisano JA (2007) Rudist taxonomy using Xray computed tomography. Paleontol Electron 10:13A http://palaeoelectronica.org/2007_3/135/index.html

Molineux A, Scott RW, Maisano J, Ketcham R, Zachos L (2010) Blending rudists with technology; non-destructive examination of the internal and external structures of rudists using high quality scanning and digital imagery. Turk J Earth Sci 19:757-767
Neo S (1987) An example of sedimentary facies analysis of reefal limestones in the Mishrif Formation in Abu Dhabi. J Jap Ass Petrol Technol 52:88-98. https://doi.org/10.3720/japt.52.88

Neo S (1996) The structural origin and relating geological framework of the upper Mishrif Formation in a Mishrif-reservoired oil field, offshore Abu Dhabi. In: Abu Dhabi International Petroleum Exhibition and Conference, 13-16 October, Abu Dhabi, UAE. Society of Petroleum Engineers, Richardson, Document ID: SPE-36203-MS. https://doi.org/10.2118/36203MS

Özer S, Meriç E, Görmüs M, Kanbur S (2009) Biogeographic distribution of rudists and benthic foraminifera: An approach to Campanian-Maastrichtian paleobiogeography of Turkey. Geobios 42:623-628

Philip J, Borgomano J, Al-Maskiry S (1995) Cenomanian-Early Turonian carbonate platform of Northern Oman: stratigraphy and palaeo-environments. Palaeogeogr Palaeoclimatol Palaeoecol. 119:77-92. https://doi.org/10.1016/ 0031-0182(95)00061-5

Racicot R (2016) Fossil secrets revealed: X-ray CT scanning and applications in paleontology. Paleontol Soc Pap 22:21-38. https://doi.org/10.1017/scs. 2017.6

Saber SG, Salama YF, Scott RW, Abdel-Gawad Gl, Aly MF (2009) Cenomanian Turonian rudist assemblages and sequence stratigraphy on the North Sinai carbonate shelf, Egypt. GeoArabia 14:113-134

Schumann D (2000) Paleoecology of Late Cretaceous Rudist Settlements in Central Oman. In: Alsharhan AS, Scott RW (eds) Middle East Models of Jurassic/Cretaceous Carbonate Systems. SEPM Spec Publ 69. Society for Sedimentary Geology (SEPM), Tulsa, pp 143-153

Scott RW (1990) Chronostratigraphy of the Cretaceous carbonate shelf, southeastern Arabia. In: AHF R, Searle MP, Ries AC (eds) The Geology and Tectonics of the Oman Region. Geol Soc London Spec Publ 49. Geol Soc, London, pp 89-108. https://doi.org/10.1144/GSL.SP.1992.049.01. 07

Seard C, Camoin G, Yokoyama Y, Matsuzaki H, Durand N, Bard E, Sepulcre S, Deschamps P (2010) Microbialite development patterns in the last deglacial reefs from Tahiti (French Polynesia; IODP Expedition \#310): implications on reef framework architecture. Mar Geol 279:63-86. https:/doi.org/10.1016/j. margeo.2010.10.013

Skelton PW, Gili E, Vicens E, Obrador A (1995) The growth fabric of gregarious rudist elevators (hippuritids) in a Santonian carbonate platform in the southern Central Pyrenees. Paleogeogr Paleoclimatol Paleoecol 119:107-126. https://doi.org/10.1016/0031-0182(95)00063-1

Skelton PW, Masse J-P (2000) Synoptic guide to Lower Cretaceous rudist bivalves of Arabia. In: Alsharhan AS, Scott RW (eds) Middle East Models of Jurassic/ Cretaceous Carbonate Systems. SEPM Spec Publ 69. Society for Sedimentary Geology (SEPM), Tulsa, pp 89-99

Sutton MD, Rahman IA, Garwood RJ (2014) Techniques for virtual palaeontology. John Wiley \& Sons, West Sussex

van Buchem FSP, Simmons MD, Droste HJ, Davies RB (2011) Late Aptian to Turonian stratigraphy of the eastern Arabian Plate -depositional sequences and lithostratigraphic nomenclature. Petrol Geosci 17:211-222. https://doi. org/10.1144/1354-079310-061

Yamamoto K, Obara H, Tusaka K, Tsuji Y, Al-Farhan ZA, Aljneibi MM, Takayanagi H, Kurita H, Sato T, Iryu Y (2016) A causal link between Paleoenvironmental dynamics and borehole instability in a Cenomanian carbonate reservoir, offshore Abu Dhabi. In: Abu Dhabi International Petroleum Exhibition \& Conference, 7-10 November, Abu Dhabi, UAE. Society of Petroleum Engineers, Richardson, Document ID: SPE-183194-MS. https://doi.org/10.2118/ 183194-MS

Yamanaka M, Nanjo T, Taniwaki T (2018) Evaluation of rudist depositional environment using $X$ ray-CT scan Late Cretaceous Cenomanian in offshore Abu Dhabi. In: Abu Dhabi International Petroleum Exhibition \& Conference, 12-15 November, Abu Dhabi, UAE. Society of Petroleum Engineers, Richardson, Document ID: SPE-192923-MS. https://doi.org/10. 2118/192923-MS

Yamanaka M, Taniwaki T, Nanjo T (2019a) Application of X-ray CT scan to slab cores for extracting Cenomanian rudist fossils in Offshore Abu Dhabi as a state-of-the-art nondestructive testing methodology. J Jap Ass Petrol Technol 84:52-58. https://doi.org/10.3720/japt.84.52

Yamanaka M, Taniwaki T, Nanjo T (2019b) Evaluation of porosity and permeability vertical distribution of rudist carbonate build up platform identified by X-ray CT and 3D modeling, Late Cretaceous Cenomanian in offshore Abu Dhabi. In: Abu Dhabi International Petroleum Exhibition \& 
Conference, 11-14 November, Abu Dhabi, UAE. Society of Petroleum Engineers, Richardson, Document ID: SPE-197747-MS. https://doi.org/10. 2118/197747-MS

Zakhera MS (2011) Cenomanian-Turonian rudists from Western Sinai, Egypt: Systematic paleontology and paleoecology. Geobios 44:409-433. https://doi. org/10.1016/j.geobios.2010.10.004

\section{Publisher's Note}

Springer Nature remains neutral with regard to jurisdictional claims in published maps and institutional affiliations.

Submit your manuscript to a SpringerOpen ${ }^{\circ}$ journal and benefit from:

- Convenient online submission

- Rigorous peer review

- Open access: articles freely available online

- High visibility within the field

- Retaining the copyright to your article

Submit your next manuscript at $\boldsymbol{\nabla}$ springeropen.com 